UJBM, Vol. 7, No. 1, January - June 2008, pp 25-28

ISSN 0975-3311 | https://doi.org/10.12725/ujbm.12.2

\title{
SELECT YOUR STYLE FOR BEST RESULTS
}

D. Fennala Agnes lylin*

\section{Introduction}

Success of a business concern is dependent upon the ability of its leadership. Leadership exists in any type of organization. Whenever and in whatever situation if someone tries to influence the behavior of another individual or a group, there is a leadership. In an organization, wherever an individual has subordinates he may act as a leader. The efforts of subordinated are to be channelised in the right direction. As leaders, they are not only responsible for directing their followers but also responsible for attaining the goals of the organization. It is believed that leaders are born and not made. At the same time, a few people also believe that leaders are not born but made. But generally, leaders are born and also made.

\section{Need or Importance of Leadership}

- Perfect organization Structure - An organization structure cannot provide for all kinds of relationships. That is why; informal relationships are made to exist within the framework or formal organization structure. But the organization structure is complete or perfect with the help of effective leadership.

*. Lecfurer in Commerce, Bishop Heber College (Autonomous), Tiruchirapalli - 620017 
- Directing group activities - The personal conduct and behavior of a leader can direct others to achieve organizational goals. The main responsibility of a leader is to get the work done effectively by the followers. The followers cannot work hard and effectively without leadership. A leader alone can consolidate the efforts and direct them towards the goal.

- Technological, economic and social changes - There are frequent changes in technology, economic and social structure in the present computer world. So, the organization should change its operation and style. This is possible only with the help of effective leadership. If the changes do not take place, the organization cannot survive.

- Better Utilization of Man Power - A leader treats with equal importance, plans, policies and programmes of an organization. The plans, policies and programmes do not work themselves. There is a need for a leader. The leader implements the plans, policies and programmes to utilize the available manpower effectively and get highest production with minimum human cost.

- Avoiding Imbalances - An organization grows in size and complexity with the imbalances. Complexity arises due to the introduction of new functions. The reason is that the introduction of new functions resulted in increased levels of management. So there is a problem of command, co-ordination and control. A leader can tackle these problems and maintain business.

- Source of Motivation - Simply, the existence of leadership does not motivate the workers. The leadership style should be utilized to motivate the workers according to the situations prevailing. The achievement of goals is doubtful in the absence of leadership.

- Fulfilling Social Responsibilities - Social responsibilities refer to the high standard of living to workers, higher productivity and income to the organization, more revenue to the government, reasonable price to the consumers and fair return on investments to the investors. These could be achieved with the help of effective leadership. Only an efficient leader can get work done to fulfill social responsibilities. 


\section{Types of Leadership}

The following are the different types of leadership which an organization can select the particular style which yields results

- The coercive leader wants things to be done. And done now. The atmosphere he creates is well, not the friendliest. Decisions are made solely at the top most level. Employees work as they are instructed. They have no liberty to take decisions independently or be creative and innovative. Sounds like a leadership style that must be avoided at any cost? The coercive leadership style helps people break unsuccessful business habits or simply make them work.

- The authoritative leadership style makes the employees see their role in a larger perspective. It places the employee's responsibilities within the purview of the organization's goals. The employee receives feedback either positive or negative that helps him grow individually and also contribute to the organistion. The mode is suitable for most organizations. One aspect that needs to be tackled carefully though when it is applied to a group of experts. An authoritative leader might come across as being pompous or know-it-all. Hence it requires careful handling.

- The affiliative style involves around the people. The leader strives to create harmony among his people and build on this resource. He shares ideas, builds trust and communicates frequently. He knows that his people are his most precious resource. This leadership is more employee-driven and motivating than those mentioned above. However, before we decide that this definitely is the best style to adopt, does note that only positive feedback does not help. An affiliative style in combo with authoritative is more advisable.

- The democratic style promotes egalitarianism within the organization. A democratic leader builds an atmosphere of trust and respect. Employee morale is high and employees know what to expect, as they are well informed and party to the decision-making. However, this option is for managers uncertain about the best way of handling things. And need ideas that they think their team can generate. Another fallout of this mode of leadership is that the regular meetings take time and not everybody can be satisfied. Crucial decisions that need to be taken urgently don't do well in these circumstances. It is advisable only if employees are not competent, informed enough, and lack team spirit as well as the skill of consensus making. 
- The pace setting leader does things fast and does them good. And he expects the same from his team. He identifies the poor performance and calls for better results. If they fail to do so they no longer belong to the team. Apparently a harsh system to follow. It works well with teams lagging behind and scant motivation or commitment. At the same time when the pace setter leaves his team becomes rudderless. Hence the approach is advisable provided the core group is self sufficient and self motivating.

- Probably the best to adopt is the coaching style leadership. But like all good things it is rare Coaching leaders identify the strengths and weaknesses of their team and help them grow. These leaders delegate extensively, as they aim at converting the employees into leaders like themselves. Feedback and instruction is common too. This style of leadership is best used when the employees are already well aware of their strengths and have the inclination to develop their leadership skills.

\section{Conclusion}

To develop good human relations between the leader and the followers an efficient leader is essential to promote self-confidence apart from motivation. Next the leader creates opportunity to show their abilities and induces the followers to work towards the accomplishments of goals. In this way, the leader promotes the co-operative attitude of workers and maintains better relations with them. 